\title{
COVID 19: SEXUALITY AND ADAPTATION IN TIMES OF PANDEMIC
}

\author{
Mgs. Maria Palacios-Tavara ${ }^{1} \boldsymbol{\Xi}$, Mgs. Gloria Torres-Romero ${ }^{2}$, Mgs. Jaime \\ Zambrano-Macias ${ }^{3}$, Mgs. Marco Calle-Gomez ${ }^{4}$, Mgs. Ingrid Gurumendi-España 5 , \\ Mgs. Alida Vallejo ${ }^{6}$ \\ 1,2, 3, 4, 5, 6 Guayaquil University Faculty of Medical Sciences, Universidad de Guayaquil, Ecuador
}

DOI: https://doi.org/10.29121/granthaalayah.v8.i7.2020.723

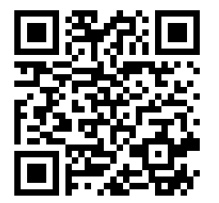

Article Type: Research Article

Article Citation: Mgs. Maria Palacios-Tavara, Mgs. Gloria TorresRomero, Mgs. Jaime ZambranoMacias, Mgs. Marco Calle-Gomez, Mgs. Ingrid Gurumendi-España, and Mgs. Alida Vallejo. (2020). COVID 19: SEXUALITY AND ADAPTATION IN TIMES OF PANDEMIC. International Journal of Research GRANTHAALAYAH, 8(7), 272-278. https://doi.org/10.29121/granthaa layah.v8.i7.2020.723

Received Date: 12 July 2020

Accepted Date: 31 July 2020

Keywords:

Coronavirus

Sexuality

Adaptation

Mortality

\begin{abstract}
Man's adaptability over time has allowed him to continue to populate the planet in ever-increasing numbers. Currently a coronavirus outbreak, SARS COV-2 is causing death and shock worldwide, due to its rapid spread, has paralyzed industries, commerce, tourism, production and the economy. In the history of mankind, various pandemics have produced high death rates worldwide. The survival of the population depends on several factors, both biological, social, psychological and also on the sexual and reproductive health of the man in his environment. Diseases caused by microscopic agents, bacteria, viruses, among others, that exist in the environment and that can be very aggressive. Plans to deal with these pathogens must be constantly updated, it is essential to assume a change of attitude regarding daily habits, adopting hygiene, food and sexual and reproductive health measures to avoid the spread of diseases and guarantee the survival of the human race. in the planet.
\end{abstract}

\section{INTRODUCTION}

In the New century, the survival of man is a new challenge when facing the changes that occur with increasing frequency, one of the most important aspects to consider is the reproduction that is based on the human sexual response that guarantees their permanence in this planet. Sexual and reproductive health represents the welfare state of man in his environment, which guarantees the coexistence of couples to exercise the perpetuation of the species through reproduction and human sexuality in optimal conditions.

Man's adaptability over time has allowed him to continue populating the planet in ever-increasing numbers. The current world population is approximately 6,000 million people and the approximately most recent of the United Nations indicate that by 2025 it will be 8,500 million, distributed in various regions of the planet.

There are factors that influence the growth of population stories such as genetics, races, cultures, geographical areas, intellect and their ability to learn have been decisive for their permanence. The great enemy of these population growths has been an almost invisible enemy, the microorganisms that exist and evolve, causing problems in people's health, some of which are very difficult to combat. In each century great pandemics occur, such as the

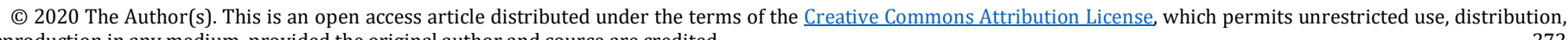
and reproduction in any medium, provided the original author and source are credited. 
black plague or the aforementioned Spanish flu, and in recent years the H1N1 flu, SARS, MERS, HIV_AIDS, Ebola, which have decreased large populations of human beings, however the curiosity of man It has allowed us to find treatments that control these diseases.

A pandemic can be defined as a disease that spreads to many countries, infecting a large part of the population, is caused by microscopic agents and causes high mortality rates worldwide. The most aggressive pandemics in recent years have been those related to the influenza virus, being a problem that threatens the permanence of man on the planet.

Despite this, the population does not seem to learn from lived experiences and does not take precautions to prevent them, since the recommendations made are not fully met. As man is a Bio-Psycho-Social unit and the fundamental basic unit of humanity, it is very important to preserve its vital functionality in optimal conditions. In this sense, it must be remembered that a healthy citizen is more productive if he or she is in good health, while it is estimated that only between $10 \%$ and $25 \%$ of the world population is completely healthy.

Currently in 2020, the coronavirus outbreak, SARS COV 2 is causing deaths and shock in all countries, as its rapid contagion has paralyzed all activities in the world, affecting industries, commerce, tourism, production, and the economy. , among other important aspects for the development of the countries, sowing panic in the population worldwide. (Ortiz J. 2020).

(COVID-19, first identified in central China on December 1, 2019 in Wuhan City, capital of Hubei Province, causes severe acute respiratory syndrome (SARS-CoV-2), may be complicated by pneumonia. It has been linked to shellfish market workers and was recognized by the World Health Organization (WHO) as a global pandemic on March 11, 2020.

Due to the ignorance of its evolution, development and form of contagion, the virus has spread rapidly through various regions, causing an uncontrollable increase in cases, raising the epidemiological curve and the collapse of health systems, with loss of human life. Due to the lack of information to define an adequate treatment, with timely medical assistance. As of July 24, 2020, more than 15 million infected people have been reported worldwide, with nearly a million deaths, including confirmed and many unconfirmed suspects. The most affected countries are; The United States is the most affected country, Spain, Italy, Germany, United Kingdom, France and Turkey, and in Latin America, Brazil, Mexico, Peru, Bolivia, among others, which is on the rise. (World Health Organization WHO 2020) Despite having health systems with established protocols in different countries, COVID 19 has determined that it is a disease from which there is still much to learn.

\section{DEVELOPING}

Health is an intangible asset that allows daily activities to be carried out in all movements of society; Man's survival depends to a great extent on his health and the relationships between human beings, both in social, cultural, psychological and reproductive aspects. Human sexual response is a complex function involving biological, psychological, affective, and sociocultural factors. (Camejo and Fuentes 2012)

Sexual and reproductive health represents the state of well-being around the facts related to reproduction and human sexuality; This phase of the human being encompasses concepts of health, understood in its historical, cultural, social and individual dimension; This experience becomes a personal practice that is born from the culture with which each one grows and is reflected in behaviors and then manifests itself in experiences and learning (Palacios M et al 2018)

The well-known SARS virus VOC 2 COVID 19 is normally transmitted from one person to another by means of small drops (known as Flügge microdroplets) that are emitted when speaking, sneezing, coughing, being very contagious and aggressive, it spreads quickly, when people are in close contact and by touching a contaminated surface and relating it to the mouth, nostrils, eyes or ears.

There is fear of the spread of this new coronavirus, this situation affects and limits the social relations and health of the population. It is likely that during the early stages of the pandemic and with the recommendations for social distancing, sexual contacts were reduced, however it is believed that there is a latent risk of contagion, both in couples and in occasional relationships. This factor could affect the number of infections that will increase with increasing sexual intercourse during the period of return to normal. It has been recognized that "after having been infected with Covid-19 there are respiratory and other vital organs sequelae that significantly affect the quality of 
Mgs. Maria Palacios-Tavara, Mgs. Gloria Torres-Romero, Mgs. Jaime Zambrano-Macias, Mgs. Marco Calle-Gomez, Mgs. Ingrid Gurumendi-España, and Mgs. Alida Vallejo

sexual intercourse, and probably these coronavirus side effects could be worse in men, since they have been found damage to the male reproductive system."

Some of the findings from a study in China on the subject reveal that "The coronavirus COVID-19 can be transmitted during sexual intercourse. The greatest risk is found in salivary drops and other fluids such as semen, and although a patient is you have cured of the Wuhan virus you can pass it on to your partner during the act. " In this work, it was detected that the virus or parts of it can remain in the semen, the investigation was developed by Weiguo Zhao of the Eighth Medical Center of the General Hospital of the People's Liberation Army of China in Beijing and Shixi Zhang of the Shangqiu Municipal Hospital in Henan. The study, which was published on May 7 in the JAMA Network Open, an expertly reviewed open access medical journal, looked at 38 men, 23 of them (60.5\%) had achieved clinical recovery and 15 (39.5\%) were in the acute stage of infection.

Given this, experts recommend taking the necessary precautions during sexual intercourse, "the virus has been found in semen, feces and orally, which is the main means of contagion." Its contagion can occur even in the simplest representations such as the kiss, which can become the greatest vector of contagion in sexual relations. "What could be critical in the prevention of virus transmission according to Dr. Pablo Mateo, director of the Department of UroOncology of the National Cancer Institute (Incart).

Regarding avoiding contagions, it is advisable to avoid sexual relations with people who pose a risk in sexual relations, such as oral sex, anal sex, and to use a mask to avoid contact with fluids, it is considered that kisses represent a potential risk. And maintain the rules of health and personal hygiene.

\section{CORONAVIRUS}

Coronaviruses ( $\mathrm{CoV})$ are a wide family of viruses that can cause various conditions, from the common cold that can cause infections of the lower respiratory system. Viruses in this family can also cause various diseases in different animals, such as dogs, cats, birds, pigs, and rodents. They are classified into four genres: alpha, beta, gamma and delta. Human coronaviruses (HCoV) are found in two of these genera: alpha coronaviruses (HCoV-229E and $\mathrm{HCoV}$ NL63) and beta coronaviruses (HCoV-HKU1, HCoV-OC43, coronavirus of the Middle East respiratory syndrome [MERS-CoV] and the acute and severe respiratory syndrome coronavirus [SARS-CoV]). Even more serious diseases are involved in gastroenteritis in infants, such as the coronavirus that causes Middle East respiratory syndrome (MERS-CoV) and the one that causes severe acute respiratory syndrome (SARS-CoV). (Arturo Galindo Fraga, et al. 2020).

According to experts, the incubation period can vary from seven to fourteen days and in which, when the test is positive, in symptomatic infected patients and those without symptoms, the tests are negative when the immune system produces antibodies after passing the illness. However, cases have been reported whose diagnosis has continued to be positive despite having been almost a month old since the onset of symptoms.

These viruses are called coronaviruses because, under the electron microscope, they appear to be protective, club-shaped projections that give the viral particle a crown-like appearance. The genome encodes four or five structural proteins (a spike protein [S], a small envelope protein [E], a membrane protein [M], a nucleocapsid protein $[\mathrm{N}]$ and, in some viruses, a hemagglutinin esterase protein (HE)), several open reading frames scattered by structural genes, as well as a polyprotein that is processed into multiple (usually 16) nonstructural proteins. These nonstructural proteins in virus replication; but they are not incorporated into the virion. Coronaviruses have also been isolated in different animals, such as birds, and in their respective species they cause a wide variety of respiratory, gastrointestinal, neurological, and systemic diseases, which have subsequently been detected in humans.

Since the mid-1960s, we have identified human coronaviruses, CoVH-229E (group 1) and CoVH-OC43 (group 2); they have been associated with the common cold and were considered relatively benign respiratory pathogens. Its genome has a homology of more than $80 \%$ with respect to previous coronaviruses. Cases must be confirmed using the RT-PCR test. (Serra Valdés MÁ. 2020.).

Only animals were believed to be transmitted to man, but transmissibility between people was demonstrated. (Yu IT, Li and Wong TW. 2004) (Song Z, Xu Y, Bao L.s / f). Detection and typing of new coronaviruses in bats and other animals has expanded knowledge of the diversity among coronaviruses, which is likely to continue. The current situation shows this. (Paules CI, Marston HD, Fauci AS. 2020) (Sarasua JM. 2020). 


\section{NEW MUTATIONS}

A new coronavirus is a new strain of coronavirus that has not been found before in humans. The first data for SARS COV 2 or also called COVID 19, was reported to the World Health Organization in Wuhan, a city located in the Chinese province of Hubei, on December 31, 2019 (WHO 2020) where the first cases of pneumonia were reported. . which was classified as a pandemic. (OPH 2020).

When people have been exposed to the virus, through an infection or a vaccine, the immune system creates specific antibodies to neutralize it, that is, to produce immunity. However, influenza viruses can mutate, change, very quickly. From time to time, influenza viruses mutate enough to produce a new strain; this process is known as antigenic tendency. People who have been exposed to a strain related to that virus have probably affected some immunity. Sometimes an abrupt change in a virus produces a very different strain from the others, this process is known as an antigenic change, producing a prevalent and serious disease.

Specialists in genomics have stated that this virus has at least two strains with different degrees of aggressiveness or virulence, this statement also maintains that the longer it passes and the more people become infected the virus has a greater chance of mutating and that this will cause the appearance of new Strains It is still unknown how genetic inheritance influences the installation and incubation period of the virus in humans, but this factor deserves a more in-depth and longer study.

Apparently this virus has a longer incubation period during which it does not emit symptoms, which allows it to spread throughout the body, settle in the lungs, where in most cases respiratory problems occur, which can range from mild to severe, or cause the death of the affected person. It is important to clarify that after the incubation, there are recent symptoms. There is a high risk factor for older adults who are more vulnerable, especially if they have diseases like diabetes, hypertension, or heart problems due to infection and death, so they emphasized greater care and protection for them.

\section{SYMPTOMS AND DIAGNOSIS}

The most common symptoms are fever, dry cough, and shortness of breath. Complications may include pneumonia, acute respiratory syndrome, or sepsis. So far there is still no specific vaccine or antiviral treatment.

Within the presumptive diagnostic parameters for COVID 19, the altered values are managed in biometrics as the white line, due to the body's defense against the virus, low platelets against the possible alteration in the activation of the coagulation system, (Coagulation disseminated intravascular) and inflammatory markers such as PCR and increased ferritin, in addition to tomographic images with ground glass images in the lungs, generally bilateral. This adds to the clinical symptoms as a background. And they are corroborated before a COVID 19 test with a positive diagnosis. Escher R. Breakey N, Lämmle B. (2020)

Phase I: early infection (day 1 to day 6-8). High viral load in the rhinopharyngeal secretions. The initial stage occurs at the time of inoculation, when the virus establishes its residence in the host, an incubation period with mild symptoms, general malaise, fever and dry cough, then the virus multiplies, focusing mainly on the system. Great viral load. Diagnosis includes a direct viral viral screening test, which can only be positive 2-3 days after the onset of symptoms, serum tests for SARS-CoV-2 IgG and IgM, along with chest imaging, complete blood count (lymphopenia and neutrophilia), liver function tests.

Phase II: Inflammatory lung (moderate): lung involvement without hypoxia (IIa) and with hypoxia (IIb) (7-10 days.) Patients affected by viral pneumonia, with cough, fever and possibly hypoxia (defined as $\mathrm{PaO} 2 / \mathrm{FiO} 2<300$ $\mathrm{mmHg}$ ). Bilateral infiltrates or opacities are seen on chest CT. Blood tests reveal an increase in lymphopenia, with increased transaminases and sometimes procalcitonin, hospitalization is required. In the presence of hypoxia, we may require mechanical ventilation and corticosteroid support.

Phase III: Systemic inflammation extra pulmonary. It manifests as a syndrome of extra pulmonary systemic hyper inflammation. At this stage, hemophagocytic syndrome, shock, vasoplegia, respiratory failure, and even multiorgan failure with systemic involvement including myocarditis may occur. Stage III treatment involves the use of corticosteroids together with cytokine inhibitors such as tocilizumab (IL-6 inhibitor) or anakinra (IL-1 receptor antagonist) and immunoglobulin (IVIG) for modulation of an immune system. In general, the prognosis is severe. (ALM de Francisco et al 2020) 
Mgs. Maria Palacios-Tavara, Mgs. Gloria Torres-Romero, Mgs. Jaime Zambrano-Macias, Mgs. Marco Calle-Gomez, Mgs. Ingrid Gurumendi-España, and Mgs. Alida Vallejo

\section{ADAPTIVE IMMUNITY}

The specificity of the culinary immune adaptive response with the development of IgG, around 7-14 days, which begins the activation phase of the disease. In the question of the positive results of the PCR, IgM and IgG, this being a critical moment in the question, the proof of the "quality" of the host immune response.

Thereafter, in a normal situation, the IgM will disappear until IgG is detectable with two possibilities:

- Positive viral PCR: in the final phase (or late stage) of the infection, or before a recurrence. In general, IgM would have disappeared by this time, although it could still be positive depending on the days of evolution of each patient.

- Negative viral PCR: we would be in a situation of cure or past infection. Negative viral PCR is variable around 14 days in pharyngeal samples. In some cases, viral PCR could be falsely negative, despite the presence of the virus, depending on the sensitivity of the test, the sample collection technique, or the viral load at that time. In some cases it will require a confirmation test.

\section{TREATMENT}

The main treatment is supportive therapy according to the symptoms, in the first instance a procedure to lower the fever with paracetamol, however, some specialists have stated that paracetamol can be harmful by influencing the loss of glutathione by oxidative stress, and has been suggested using novalgine or dipyrone.

Treatment with chloroquine or hydroxychloroquine has also been suggested in other countries, associated with the use of azithromycin and supported with an antiretroviral such as oseltamivir. But of this treatment there are also criticisms especially for the adverse effects in relation to cardiac complications mainly, even more so in people at risk such as hypertensive, diabetic, or immunosuppressed patients, among the last options, ivermectin was also mentioned as another alternative, simultaneously They have mentioned the possibility of using the plasma of people who have overcome the virus, while new drugs are presented and studies are carried out, some laboratories report that a vaccine is being worked to combat the virus, but it takes at least a year to launch it to the market and the adverse effects that it could generate are unknown.

Meanwhile, efficient and recognized resources are needed to boost the immune system, such as immunomodulators, mega doses of vitamin $C$ and acetylcysteine to support the lower impact of the virus on the body, in the same way it will always be important to protect the liver with B complex. Until you define a treatment guide that does not involve risks of complications or adverse effects, insist on applying recommended prevention measures that include washing hands, covering your mouth when coughing, the physical distance between people and the use of masks, in addition to self-isolation. And follow-up for people suspected of being infected. While clinical trials are continued to find the vaccine and treatments treated. (ALN de Francisco et al 2020)

\section{CONCLUSION}

Pandemics worldwide are a problem that affects human life for centuries past, yet the population has not yet adequately avoided it. The appearance of this virus has altered the life of the human race, the world will not be the same from now on, so there is a new way of living in society, the social distance of at least 2 meters to avoid contagion.

SARS COV 2 or also called coronavirus is an extremely aggressive virus, with high contagion and high mortality, silent in its incubation period, which must be studied in depth by the scientific community, to find ways to prevent its advance. It is essential that scientists deepen their knowledge about this and other pathogens that affect the health of the population, to prevent the death of people and improve the quality of life for future generations.

To face COVID 19, there are several proposals, but none are definitive, however, it is being applied as antiretroviral treatment to prevent virus replication and avoid viral overload, generating a better immune response with the development of antibodies, more correct handling of signs of inflammatory response in the cytokine storm phase, to reduce mortality in contaminated patients.

Finally, it is important to recognize that living with millions of microorganisms that can seriously affect life affects us. Sexual and reproductive health represents an essential factor in human survival, it must implement healthy procedures and preventive measures to face the COVID 19 pandemic and guarantee the survival of the 
Covid 19: Sexuality and Adaptation in Times of Pandemic

species. Plans to deal with these pathogens must be constantly updated, it is essential to assume a change of attitude regarding daily habits, lifestyle and activities, adopting strict hygiene measures for the survival of the human race on the planet.

\section{SOURCES OF FUNDING}

This research received no specific grant from any funding agency in the public, commercial, or not-for-profit sectors.

\section{CONFLICT OF INTEREST}

The author have declared that no competing interests exist.

\section{ACKNOWLEDGMENT}

None.

\section{REFERENCES}

[1] Sullivan S.J., Jacobson R.M., Dowdle W.R., Poland, G.A. 2009 H1N1 influenza. Mayo Clin Proc. 2010 January; 85(1): 64-76.

[2] CDC. CDC estimates of 2009 H1N1 influenza cases, hospitalizations and deaths in the United States, April 2009 - February 13, 2010.

[3] Camejo, L. y Fuentes, S. (2012). La Sexualidad en la Mujer Embarazada.México: 2a ed. Ed.McGraw HillInteramericana

[4] OMS 2020. Coronavirus El mapa mundial del coronavirus: tres millones de casos y más de 223.000 muertos en todo el mundo. https://www.rtve.es/noticias/20200429/mapa-mundial-del-coronavirus/1998143.shtml

[5] Racaniello, V. Influenza A/Mexico/2009 (H1N1) - questions \& answers. Virology Blog. May 13, 2009.

[6] Ortiz Jorge. 2020 Las pandemias y su huella en la historia de la humanidad Ecuador Disponible en: https://www.primicias.ec/noticias/firmas/grandes-pandemias-huella-historia-humanidad

[7] Torres Romero, G. del C., Palacios Tavara, M. del S., Zambrano Macías, J. S., \& Vallejo López, A. B. (2019). Comportamiento y conducta sexual en gestantes. RECIMUNDO, 3(2), 860-881. https://doi.org/10.26820/recimundo/3.(2).abril.2019.860-881 https://recimundo.com/index.php/es/article/view/480/555

[8] Arturo Galindo Fraga, Eric Ochoa Hein, José Sifuentes Osornio. 2020 Nuevo Coronavirus (nCoV) 2019-2020 http://www.incmnsz.mx/2020/Coronavirus.pdf

[9] Serra Valdes MÁ. Infección respiratoria aguda por 2019-nCoV: una amenaza evidente. Revista Habanera de Ciencias Médicas [revista en Internet]. 2020 [citado 2020 Abr 13];19(1):[aprox. 4 p.]. Disponible en: http://www.revhabanera.sld.cu/index.php/rhab/article/view/3171

[10] Geo. F. Brooks, Karen C. Carroll, Janet S. Butel, Stephen A. Morse, Timothy A. Mietzner 2014. Madrid. Microbiologia https://accessmedicina.mhmedical.com/content.aspx?bookid=1507\&sectionid=102896371

[11] Ignatius T.S. Yu, M.B., B.S., M.P.H., Yuguo Li, Ph.D., Tze Wai Wong, M.B., B.S.,

[12] Wilson Tam, M.Phil., Andy T. Chan, Ph.D., Joseph H.W. Lee, Ph.D., Dennis Y.C. Leung, Ph.D., and Tommy Ho, B.Sc. Evidence of Airborne Transmission of the Severe Acute Respiratory Syndrome Virus. $2004 \mathrm{~N}$ Engl J Med [Internet]. $2004 \quad$ [Citado 30/01/ 2020]; 350(17):1731-9. Disponible en: https://www.nejm.org/doi/pdf/10.1056/nejmoa032867

[13] Song Z, Xu Y, Bao L. From SARS to MERS, thrusting coronaviruses into the spotlight. Viruses [Internet]. 2019 [Citado 30/01/ 2020]; 11(1):11. Disponible en: https://www.mdpi.com/1999-4915/11/1/59/pdf

[14] Paules CI, Marston HD, Fauci AS. Coronavirus Infections-More Than Just the Common Cold. JAMA [Internet]. 2020 [Citado 23/01/ 2020]; $323 \quad$ (8):707-708. Disponible https://jamanetwork.com/journals/jama/fullarticle/2759815 
Mgs. Maria Palacios-Tavara, Mgs. Gloria Torres-Romero, Mgs. Jaime Zambrano-Macias, Mgs. Marco Calle-Gomez, Mgs. Ingrid Gurumendi-España, and Mgs. Alida Vallejo

[15] Sarasua JM. ¿Qué sabemos hasta el momento del posible brote de nuevo coronavirus (2019-nCoV)? Noticias y Perspectivas. Medscape [Internet]. 23 de enero de 2020. [Citado 23/01/ 2020]. Disponible en: https://espanol.medscape.com/verarticulo/5904929?src=mkm_latmkt_200131_mscmrk_top5latam_nl\&uac $=226682 \mathrm{DK} \& \mathrm{impID}=2261519 \& \mathrm{faf}=1$

[16] OPS. Virus respiratorio emergente, incluido el COVID-19: métodos de detección, prevención, respuesta y control. Campus Virtual de salud pública. 2020 (Internet) Disponible en https://www.campusvirtualsp.org/es/node/28738

[17] Ministerio de salud pública de Ecuador, Boletines epidemiológico del coronavirus. COVID 192020 https://www.salud.gob.ec/actualizacion-de-casos-de-coronavirus-en-ecuador/

[18] Autor/a: Yan Zhang, M.D., Meng Xiao, M.Sc. Shulan Zhang, M.D. Peng Xia, M.D. Wei Cao, et al. Wei Jiang, M.D. Fuente: NEJM DOI: 10.1056/NEJMc2007575 Coagulopathy and Antiphospholipid Antibodies in Patients with Covid-19 https://www.nejm.org/doi/full/10.1056/NEJMc2007575?query=featured_coronavirus

[19] ALM de Francisco 1, JL Pérez Canga1, Ramón Agüero2. Coronavirus y Riñón. Últimas Novedades 12 de Abril de 2020 https://www.nefrologiaaldia.org/es-articulo-coronavirus-rinon-ultimas-novedades-12-297

[20] El comercio. pa. Coronavirus EN VIVO por Google Maps: así avanza la pandemia y los casos en todos los países del mundo https://mag.elcomercio.pe/data/pandemia-coronavirus-en-google-maps-sigue-en-vivo-laexpansion-del-covid-19-en-todo-el-mundo-google-maps-mapa-maps-como-prevenir-que-es-real-timetiempo-real-smartphone-aplicaciones-apps-estados-unidos-colombia-ecuador-argentina-mexico-perunnda-nnrt-noticia/?ref=ecr

[21] Vallejo López, A. B., Peñafiel Pazmiño, M., Kou Guzmán, J., \& Álvarez Reyes, S. J. (2018). Formar investigadores en el área de la salud del siglo XXI. RECIMUNDO, 2(2), 137-147. Recuperado a partir de https://recimundo.com/index.php/es/article/view/223 https://recimundo.com/index.php/es/article/view/223/pdf

[22] Álvarez Lires, M., Arias, A., Pérez Rodríguez, U., Serrallé, J. F. (2013). La historia de las ciencias en el desarrollo de competencias científicas. Enseñanza de las Ciencias, 31 (1), pp. 213-233 [Online] file://C:/Users/Hp\%204000\%20C2D/Downloads/391-881-1-PB.pdf. 